\title{
O JUDICIÁRIO BRASILEIRO TEM AMADURECIMENTO DEMOCRÁTICO PARA O NÃO POSITIVISMO?
}

\section{Bárbara Amelize Costa*}

Resumo: Este artigo analisa, a partir do contexto social dos anos de 2012 a 2018, a maturidade judiciária do Estado Brasileiro para adoção das teorias juspositivistas. Se, por um lado, há determinado consenso contemporâneo dentro da Teoria e Filosofia do Direito acerca da não existência de uma democracia fora do Não-Positivismo, por outro, a avalanche de acontecimentos políticos que culminaram em atuações vacilantes das instituições jurídicojudiciárias do país conduzem ao questionamento se só estaríamos preparados para as bases de um positivismo inclusivo.

Palavras-chave: positivismo; juspositivismo; decisionismo; judiciário; filosofia.

\section{HAS THE BRAZILIAN JUDICIARY GOT ENOUGH DEMOCRATIC MATURITY FOR LEGAL NON-POSITIVISM?}

\begin{abstract}
This article analyses the maturity of the Brazilian State concerning the adoption of Juspositivism theories, having the social context of the years 2012 to 2018 as a starting point. If, on the one hand, there is a certain contemporary consensus within the Theory and Philosophy of Law regarding the non-existence of a democracy outside Non-Positivism; on the other hand, the avalanche of political events that culminated in the faltering performances of the Legal and Juridical Institutions of the country have brought up the question of whether or not Brazil is prepared for the basis of an Inclusive Positivism.
\end{abstract}

Key words: positivism; juspositivism; decisiveness; judiciary; philosophy.

\section{INTRODUÇÃO}

A polarização política que apresentou significativo acirramento nas eleições presidenciais do ano de 2012, os movimentos sociais de 2013, a destituição da presidenta Dilma Rousseff, o arquivamento do processo na Câmara dos Deputados das denúncias por corrupção do político que assumiu seu posto, o alcance político-judiciário da operação Lava Jato, o encarceramento do ex-Presidente Luiz Inácio Lula da Silva e a escalada dos discursos de ódio representam alguns dos fatos sociopolíticos que vêm alterando a sistemática jurídica

\footnotetext{
${ }^{*}$ Mestranda e bolsista CAPES em Teoria do Direito pela Pontifícia Universidade Católica de Minas Gerais. Especialista em Tecnologias aplicadas à Educação pela Pontifícia Universidade do Rio de Janeiro. Bacharel em Direito e em Ciência da Computação pela PUC Minas. Advogada. Email: barbaraamelize@gmail.com. Residência: Rua Santo Agostinho, 964, Apt 301, Sagrada Família, Belo Horizonte, Minas Gerais, CEP 31035480.
}

Rev. de Teorias e Filosofias do Estado | e-ISSN: 2525-9652 | Porto Alegre | v. 4 | n. 2 | p. 01 - 17 | Jul/Dez. 2018 
do país. Se, por um lado, a referida avalanche de acontecimentos reativou, de alguma forma, a participação popular nos processos jurídicos decisórios, por outro, a atuação vacilante das instituições político-judiciárias parece colocar em cheque a estabilidade de direitos sociais e as garantias penais constitucionais conquistadas.

A gravação ilegal de áudios envolvendo a presidenta da república Dilma Rousseff, os vazamentos à mídia dos conteúdos de áudios de investigação criminais, a questionável legalidade do processo de seu "impeachment", o devido processo legal atropelado por rompantes jurídicos de juízes de primeiro grau, a intervenção militar no Estado do Rio de Janeiro, a execução provisória de sentença sem trânsito em julgado de sentença penal condenatória e sem previsibilidade no código de processo penal, as nuances atípicas que afetam o processo judicial do Presidente Luís Inácio Lula da Silva tratam-se de meras exemplificações de hermenêuticas interpretativas expansivas da Constituição da República Federativa do Brasil e das legislações infraconstitucionais.

Frente a estes cenários, faz-se necessário questionar se os quase completos trinta anos da Constituição não foram suficientes para consolidar as garantias constitucionais arduamente conquistadas pós período ditatorial. Se vários posicionamentos do judiciário brasileiro - desde o $1^{\circ}$ grau até a Suprema Corte - apontam para um decisionismo crasso, escancaradamente vinculado ao uso malicioso de teorias juspositivistas - usadas, ora de forma direta e declarada, ora, veladamente, desvirtuando suas premissas - não se pode olvidar em questionar se o positivismo inclusivo não se apresenta mais adequado à maturidade do judiciário atuante, na contemporaneidade, no país.

É cediço que o positivismo jurídico clássico não fornece as bases para uma perspectiva de realizabilidade social. A eficácia como fator condutor de constitucionalidade e a juridicidade dos princípios como normas constitucionais de força cogente não se coadunam com os preceitos meramente formais e legais da ciência do Direito encarada na perspectiva positivista. Por outro lado, também é aviltante que todas as respostas dadas aos possíveis problemas do decisionismo crasso ainda não foram suficientemente desenvolvidas e concretizadas para impedir as nocividades do ativismo judicial desenfreado.

Como tentativa de apontar os primeiros indícios para enfrentamento desta questão, pretende-se, neste artigo, resgatar os caminhos teóricos jurídicos que nos conduziram do jusnaturalismo ao juspositivismo. Nestes termos, no segundo capítulo do presente artigo apresentar-se-ão, os conceitos de jusnaturalismo e do positivismo clássico, com enfoque, 
quanto a este, na teoria puritanista até o giro decisionista em Kelsen. No terceiro capítulo abordar-se-ão, a emersão dos estados constitucionais e o papel dos princípios na esfera póspositivista. No quarto capítulo abordar-se-ão as influências do desvirtuamento das teorias póspositivistas para a caoticidade do cenário político brasileiro. A guisa de conclusão, apresentarse-á argumentos vinculados a um possível recuo técnico-jurídico das teorias juspositivistas.

\section{DO JUSNATURALISMO AO POSITIVISMO JURIDICO KELSENIANO}

Compreendendo, nos termos de Nussbaum (1995, p.17), que a concepção técnicocientífica da racionalidade pública - como derivação do utilitarismo econômico - apresenta uma confiança excessiva nos métodos técnicos para modelar a conduta humana e que a imaginação literária mantem-se como um caminho viável para alcance de uma racionalidade mais humanista na política e nos procedimentos do Direito, tem-se que a tragédia grega de Antígona (escrita por Sófocles) ainda traduz, da forma mais cristalina, o alcance do que se define pela compreensão de jusnaturalismo e positivismo. Se, por um lado, um trataria de aspectos do sagrado - vinculadas ao metafísico e a uma ordem superior à existente, imutável e atemporal - o outro, por sua conta, vincular-se-ia a mera falabilidade humana na condução das razões da sociedade.

Conforme se depreende do trecho onde Antígona responde ao Rei Creonte por ter sepultado seu irmão e, a ele, rendido todas as libações de uma inumação digna, mesmo em arrepio ao decreto por este ditado, têm-se a extensão das dimensões da ética, da moral e da religiosidade em que o Direito se via atordoamente misturado.

Creonte

[...] Sabias que, por uma proclamação, eu havia proibido o que fizeste?

Antígona

Sim, eu sabia! Por acaso poderia ignorar, se era uma coisa pública?

Creonte

E apesar disso, tiveste a audácia de desobedecer a essa determinação?

Antígona

Sim, porque não foi Júpiter que a promulgou; e a Justiça, a deusa que habia com as divindades subterrâneas, jamais estabeleceu tal decreto entre os humanos; nem eu creio que teu édito tenha força bastante para conferir a um mortall o poder de infringir as leis divinas, que nunca foram escritas, mas são irrevogáveis; não existem a partir de ontem, ou de hoje; são eternas, sim! E ninguém sabe desde quando vigoram" - Tais decretos, eu, que não temo o poder de homem algum, posso violar sem que por isso me venham a punir os deuses! Que vou morrer, eu bem sei; é inevitável; e morreria mesmo sem a tua proclamação. E, se se morrer antes do meu

Rev. de Teorias e Filosofias do Estado | e-ISSN: 2525-9652 | Porto Alegre | v. 4 | n. 2 | p. 01 - 17 | Jul/Dez. 2018 
tempo, isso será, para mim, uma vantagem, devo dizê-lo! Quem vive, como eu, no meio de tão lutuosas desgraças, que eprde com a mode? Assim, a sorte que me reservas é um mal que não se deve levar em conta; muito mais grave teria sido adminitir que o flho de minha mãe jazesse em sepultura; tudo o mais me é indiferente! Se te parece que cometi um ato de demência, talvez mais louco seja quem me avusa de loucura! (SÓFOCLES, 496 AC - 406 AC)

É na escola da Exegese - no contexto do Estado Moderno - que os esforços para elevação de uma concepção formalista-normativista, dissociada, pois, de toda a dimensão ética, moral e religiosa presentes na Antiguidade, criam corpo. Apesar de todo o engendramento, as teorias positivistas emanadas de tal escola, ainda não foram capazes de suprimir todos os elementos sociológicos e axiológicos - traduzidos em valores morais e, no mínimo, éticos - na compreensão do que era o Direito.

Kelsen, teórico alemão de tradição civil law, apresenta-se como o divisor de águas para uma separação consistente entre Direito e Moral. Levando o positivismo às últimas consequências e propondo uma ciência autônoma, puritanista, livre do sincretismo metodológico, propõe a compreensão de um Estado de Direito centrado na base formal do texto legal com sua Teoria Pura do Direito.

\begin{abstract}
De um modo inteiramente acrítico, a jurisprudência tem-se confundido com a psicologia e a sociologia, com a ética e a teoria política. Esta confusão pode porventura explicar-se pelo fato de estas ciências se referirem a objetos que indubitavelmente têm uma estreita conexão com o Direito. Quando a Teoria Pura empreende delimitar o conhecimento do Direito em face destas disciplinas, fá-lo não por ignorar ou, muito menos, por negar essa conexão, mas porque intenta evitar um sincretismo metodológico que obscurece a essência da ciência jurídica e dilui os limites que lhe são impostos pela natureza do seu objeto. (KELSEN, 1999, p.12)
\end{abstract}

O Direito, como objeto específico da dogmática jurídica kelseniana, apresenta um contorno específico: o direito positivo definido pelo ato de vontade institucionalizado através de um processo racional-burocrático. As normas jurídicas - como forma deste direito - são tidas, então, como preceitos de "dever-ser" que ordenam, proíbem, permitem e atribuem poderes e competências. Até a Teoria Pura, concebia-se o Direito como formado por dois elementos: um primário - traduzido na conduta humana que preceituaria uma norma de dever ser e, um secundário - tido como a descrição da sanção. Esta estruturação, todavia, na concepção kelseniana, não se mostrou suficiente para diferenciar o Direito da Moral e nem de nenhuma outra ordem social. 
A moral - como ordem social vigente - também apresentava proposições prescritivas (fazer o certo e o justo) e prescrições sancionatórias (conduta social perante os demais membros da convivência social). Se ambas mantinham a estrutura prescritiva de dever ser e prescritiva de sanção - o que diferenciaria o Direito da moral seria, então, a forma de sancionar.

Na moral ter-se-ia uma sanção transcendente e, no âmbito jurídico, uma sanção imanente. Estas, diversamente daquelas que consistem na simples aprovação ou desaprovação, seriam socialmente organizadas. A distinção entre Direito e Moral não poderia se encontrar naquilo que as duas ordens sociais prescreviam ou proibiam, mas, sim, no como elas prescreviam ou proibiam determinada conduta. Norberto Bobbio (2003, pg.54) - jurista que aprimorou a teoria kelseniana sem, contudo, desvencilhar-se das suas principais premissas teóricas basilares - apontou, todavia como critério de diferenciação a resposta à violação.

O Direito, então, nos termos kelsenianos, só poderia ser distinguido da moral quando concebido como uma ordem de coação - isto é, como ordem normativa que procura obter determinada conduta humana ligando a conduta oposta a um ato de coerção socialmente organizado. Nisto consiste a subversão da ordem da estrutura da norma, onde a prescrição de coerção (e sua forma imanente) é o elemento primário que distingue o direito das demais ordens sociais.

\footnotetext{
A tese de que o Direito é, segundo a sua própria essência, moral, isto é, de que somente uma ordem social moral é Direito, é rejeitada pela Teoria Pura do Direito, não apenas porque pressupõe uma Moral absoluta, mas ainda porque ela na sua efetiva aplicação pela jurisprudência dominante numa determinada comunidade jurídica, conduz a uma legitimação acrítica da ordem coercitiva estadual que constitui tal comunidade. (KELSEN, 1999, p. 60)
}

Diferentemente das ciências naturais, onde o descumprimento de uma norma leva, necessariamente, a um único e mesmo resultado - princípio da causalidade -, o que existe no Direito é uma possibilidade sancionatória (elemento de probabilidade). Se nas ciências naturais tem-se que "Quando é A, b também é ou será", no Direito, "Quando A é”, "B deve ser”. A eficácia na teoria pura do Direito, então, não se relaciona à concepção casualista, mas à ideia de imputação de probabilidade. A eficácia da norma jurídica se expressa pelo nexo de imputação entre conduta e sanção. Nestes termos, o princípio da imputação é um pressuposto de análise científica do direito.

Rev. de Teorias e Filosofias do Estado | e-ISSN: 2525-9652 | Porto Alegre | v. 4 | n. 2 | p. 01 - 17 | Jul/Dez. 2018 
As normas jurídicas, contudo, sozinhas e desconectadas, não produzem o Direito. Para se sustentarem, careceriam de uma estrutura organizada e hierárquica que produziria um todo com sentido. Se o Direito é concebido como um sistema ordenado e hierárquico de normas passar-se-ia, então, à necessidade de fundamentar a unidade desta pluralidade. Nestes termos, Kelsen especificaria que o fundamento de validade de uma norma apenas poderia ser a validade de outra norma - que a ela seria superior. Todavia, para não se perder no interminável esta correlação, criou a noção de norma jurídica fundamental. A norma fundamental não se trata, pois, de um ato de vontade, mas sim de uma estratégia de fechamento lógico. Seria a norma fundamental que constituiria a unidade de uma pluralidade de normas enquanto representaria o fundamento da validade de todas as normas pertencentes a essa ordem normativa.

O ordenamento jurídico em movimento - dinâmica jurídica - compreende-se pela produção e aplicação do Direito. Na dinâmica estática tem-se o direito como um sistema de normas em vigor onde a natureza do fundamento de validade (dinâmica jurídica ou dinâmica estática) pode estar pautada pelo princípio estático ou pelo princípio dinâmico.

A dinâmica jurídica segundo o princípio estático fornece não só o fundamento de validade, mas também, o conteúdo de validade das normas dela deduzidas através de operação lógica. Trata-se de uma dedução que reconduz a uma norma tida como imediatamente evidente - não sendo resultado de um ato de vontade - mas, sim, tida como natural.

A dinâmica jurídica segundo o princípio dinâmico, por sua vez, se apoia na criação de outra norma e não no conteúdo desta - é norma válida porque foi produzida por autoridade competente demonstrando a fluidez e, portanto, a inexistência de conflitos. Nestes termos, Kelsen compreende o direito segundo a dinâmica jurídica pelo princípio dinâmico o que, em última análise, significa fundamentar a validade do Direito como o próprio Direito (autorreferencialidade).

A norma jurídica não vale porque tem determinado conteúdo, mas porque é criada por uma forma determinada. Nestes termos, qualquer conteúdo pode se tornar Direito. Se se perguntasse o fundamento de validade de uma norma jurídica, a resposta iria consistir na condução à norma fundamental desta ordem jurídica.

De forma simplista, todavia, objetiva, Kelsen traduz o Estado Legislativo do Direito, onde se pode determinar que, essencialmente e puramente, é valido o que está descrito na lei - 
minimizando o papel do juiz que passa a ser aquele que amolda a conduta à norma ("boca da lei").

Esta visão lógica-racionalista, todavia, acaba sendo relativizada a partir do Capítulo 8 da Teoria Pura do Direito. Nele, Kelsen divide os intérpretes do Direito em intérpretes autênticos (chefe de poder executivo, legislativo, juiz, servidores) e intérpretes não autênticos (professores, juristas, estudiosos). Aos intérpretes autênticos, dentro do processo hermenêutico interpretativo, caberia escolher uma decisão dentre as várias decisões válidas de um ordenamento (moldura). Aos não autênticos caberia, tão somente, listar as possibilidades de decisões válidas - sem dizer qual é a melhor e a mais oportuna.

A dinâmica da atuação da interpretação autêntica, então, está no ato de vontade do intérprete autêntico - que passa a escolher uma das várias decisões válidas possíveis dentro da moldura do ordenamento. Ao tratar deste processo hermenêutico, Kelsen passa a admitir que a polissemia inerente às normas - e à linguagem - possa conduzir a decisões que se tornam válidas, mesmo que contrárias ao Direito Positivo (decisões fora da moldura) na mesma mão que juristas como Hart - de tradição common law. Esta compreensão conduz ao giro ao decisionismo que marca, no futuro, a crise do Positivismo culminando numa transição ao Estado Constitucional de Direito e às Teorias PósPositivistas.

\section{OS ESTADOS CONSTITUCIONAIS DE DIREITO E OS PRINCIPIOS}

Nas Revoluções Francesa e Americana - engendradas em ideais iluministas, o Estado de Direito ganha seus contornos mais relevantes. Fortalece-se, aí, a positivação de normas (movimentos constitucionais ou constitucionalismos nacionais) com vistas à limitação dos poderes reais. O Estado de Direito (Estado Liberal, Estado Social e Estado Democrático) e as fases intermediárias entre eles estabelecem a estrutura constitucionalista como modelo jurídico de sociedade.

O Estado de Direito se forma tanto empírica como normativamente por meio de uma relação de tensão entre direito e política que culmina, invariavelmente, na forma de absorção social dos direitos fundamentais, que serão consolidadas por meio do instrumental formal denominado Constituição. (Habermas, 1997, p.170).

Rev. de Teorias e Filosofias do Estado | e-ISSN: 2525-9652 | Porto Alegre | v. 4 | n. 2 | p. 01 - 17 | Jul/Dez. 2018 
O Estado Liberal típico traduziu-se no triunfo do Liberalismo a partir dos ideais individualistas e, de liberdade e igualdade - identificadas numa estrutura de obrigações negativas do Estado - que culminaram, ao final, em fortes desigualdades sociais:

\begin{abstract}
Esse individualismo dos séculos XVII e XVIII corporificado no Estado Liberal e a atitude de omissão do Estado diante dos problemas sociais e econômicos conduziu os homens a um capitalismo desumano e escravizador. O século XIX conheceu desajustamentos e misérias sociais que a Revolução Industrial agravou e que o Liberalismo deixou alastrar em proporções crescentes e incontroláveis. Combatida pelo pensamento marxista e pelo extremismo violento fascista, a liberal democracia viu-se encurralada. $\mathrm{O}$ estado não mais podia continuar se omitindo perante os problemas sociais e econômicos (MAGALHÃES, 2002, p. 44).
\end{abstract}

Foi a Primeira Guerra Mundial que trouxe a percepção de necessidade de reconhecimento de existência digna, preocupação com o social e o econômico - cobrando do Estado uma conduta menos abstencionista. Neste processo novos direitos sociais foram reconhecidos culminando nas chamadas obrigações positivas do Estado.

O Welfare State (Estado Social), todavia, não conseguiu sustentar o aumento exacerbado de prestações estatais - o que culminou em grandes crises financeiras e indisposição dos cofres públicos. Ademais, pela postura de não discussão das necessidades reais com a àqueles que teriam mais legitimidade em dizê-las, o modelo jurídico de sociedade, acabou voltando-se às versões ditatoriais.

\title{
A ocorrência do Estado Totalitário fascista e da Segunda Guerra Mundial
} demandaram uma resposta social mais efetiva - que gerou um fortalecimento dos ideais neoliberalistas:

Os neoliberais apresentam uma solução para a crise que o Estado Social, naquele momento, não era capaz de superar. Para superá-la era necessário criar-se as condições para acumulação e expansão do capital, com a posterior criação de riquezas e empregos. Para que o capital se expandisse era necessário que o Estado criasse as seguintes situações ideais: 1. Diminuição do Estado com processos de privatização, permitindo que o setor privado pudesse atuar naqueles setores onde o Estado era concorrente ou único ator. 2. Com a diminuição do Estado, inclusive nas suas prestações sociais fundamentais, é possível a diminuição ou eliminação dos tributos do capital, deixando que a classe assalariada arque com o que subsiste dos serviços públicos (os dados do período Reagan nos EUA ilustram essa afirmativa). 3. Enfraquecimento dos sindicatos para que não haja pressão suficiente sobre o valor do trabalho ameaçando os lucros crescentes. 4. Para enfraquecer os sindicatos são necessárias políticas econômicas de geração do desemprego, com a substituição gradual do trabalho humano pela automação (o capital tem investimento maciço em serviços e bens sofisticados para ampliação dos lucros, aumentando o consumo sem aumentar os consumidores, permitindo assim, também, a geração do desemprego, o que pode parecer incompatível). 5. Com o enfraquecimento dos sindicatos, há uma

Rev. de Teorias e Filosofias do Estado | e-ISSN: 2525-9652 | Porto Alegre | v. 4 | n. 2 | p. 01 - 17 | Jul/Dez. 2018 
diminuição dos salários em determinada área de produção (perdem seu valor real com uma inflação controlada, que permita a sua diminuição sem afetar o setor produtivo; em outras palavras, há inflação, mas sob controle. 6. Com o enfraquecimento dos sindicatos, há a diminuição dos direitos sociais, especialmente os direitos constitucionais do trabalhador, o que significa um retorno às características da terceira fase evolutiva do Estado (MAGALHÃES, 2002, p. 72).

A disparidade entre as propostas neoliberais e as necessidades de trabalho e bemestar social somados à falência do Estado Social desembocaram na tentativa de construção de um Estado Democrático de Direito - que visou transformar, de forma paradigmática, o papel da Constituição. Nesta nova fase tem-se como núcleo axiológico, o princípio da dignidade da pessoa humana. Passa-se, então, à compreensão do Direito não mais como um manual de regras, mas de regras e princípios.

O processo de racionalização - projeto moderno da sociedade - que tem seu início identificado nas ideias kantianas e segue até os tempos atuais, alcança o Direito. A busca pela razão jurídica provoca um processo de compreensão hermenêutica que tem a premissa de que todo texto traz a expectativa de um sentido imediato. Esta compreensão culmina em marcos paradigmáticos do entendimento e compreensão do próprio Direito e da juridicidade de suas normas.

É a partir dos trabalhos fundamentais de Hans-Georg Gadamer que se sabe que o trabalho interpretativo é apenas uma parte de todo o trabalho de leitura e interpretação de textos, isto é, o trabalho de leitura de um texto não leva apenas ao trabalho mecânico de interpretação do mesmo, mas, antes, a uma relação de circularidade entre compreensão, interpretação e aplicação, abrangida, ainda, por uma relação de envolvimento entre o texto e o leitor - o que, necessariamente, conduz ao impedimento de uma interpretação asséptica e neutra. (OMMATI, 2015, p. 95)

Nesta mesma toada, Heidegger (HEIDEGGER, 2000, p.102) descreve que a essência do homem (entendida como Daesin) é a mudança, evidenciando que a ideia de criação de uma linguagem matemática destituída de subjetividade, capaz de fornecer a essência (ou espírito) do que é lido é inadequada e inconsistente.

Gadamer (2003, pg. 89), a partir da concepção Heideggeriana sobre a linguagem, aponta a historicidade dos seres e a evidência de que todo o nosso mundo é um mundo de texto e de interpretações feitas destes textos - demonstrando a fluidez da linguagem a partir da construção histórica de cada indivíduo.

Rev. de Teorias e Filosofias do Estado | e-ISSN: 2525-9652 | Porto Alegre | v. 4 | n. 2 | p. 01 - 17 | Jul/Dez. 2018 
Neste mesmo sentido, Wittgenstein (1996, pg. 10-117), aponta que a compreensão de algo estaria vinculado à situação histórica em que a frase é usada e não, apenas, ao ato de significação prévia e rígida que ela possa ter no indivíduo. E, Kuhn (1997, pg.25), por sua vez, mostra a importância do preconceito, da tradição e das práticas sociais e a não linearidade evolutiva das ciências.

Todos estes autores da hermenêutica filosófica demonstraram, para o Direito, a falência de uma concepção puritanista calcada em regras. É a força normativa dada aos princípios que permitiria ao Direito verdadeiras revoluções paradigmáticas na construção de uma realizabilidade social. No paradigma do Estado Liberal, os princípios eram considerados meras abstrações cuja normatividade era nula ou duvidosa. Já no Estado do Bem Estar Social e com as ascensão das teorias juspositivistas, a força cogente dos princípios começa a tomar corpo.

Na concepção de Alexy (1997, pg. 33), e dentro da acepção de Dworkin, o grande equívoco dos positivistas seria o de terem concebido o ordenamento jurídico apenas como um conjunto de regras, quando, na verdade, o ordenamento jurídico é bem mais complexo e seria formado por regras e princípios - base da compreensão do modelo pós-positivista, próprio do Estado Democrático de Direito.

Há, nesta via, um resgate e uma reaproximação do Direito com a Moral, já que no modelo pós-positivista, a juridicidade é norteada pela noção de justiça. As noções de justo e injusto, ainda que causem soluções jurídicas diversas nos casos concretos e, ainda, os princípios jurídicos, conforme informado, passam a ser alçados ao patamar de normas ao lado das regras conforme palavras de Bonavides: “[...] (o paradigma) pós-positivista corresponde às duas últimas décadas do século $\mathrm{XX}$, em que os princípios se convertem no fundamento de toda a ordem jurídica como princípios constitucionais” (BONAVIDES, 1994, p. 265).

Ronald Dworkin, de tradição common law, por sua vez, entende que o Direito é todo eminentemente interpretativo e, nesta via, uma questão de princípios que não entram em colisão já que podem ser harmonizados por uma interpretação coerente (OMMATI, 2015, p. 162-188), traduzindo o direito como um todo integrado:

Em primeiro lugar, insiste em que a decisão judicial deve ser uma questão de princípio, não de conciliação, estratégia ou acordo político (...). Em segundo lugar, (...), a integridade se afirma verticalmente: ao afirmar que uma determinada liberdade é fundamental, o juiz deve mostrar que sua afirmação é compatível com princípios embutidos em precedentes do Supremo Tribunal e com as estruturas 
principais de nossa disposição constitucional. Em terceiro lugar, a integridade se afirma horizontalmente: um juiz q/ue adota um princípio em um caso deve atribuirlhe importância integral nos outros casos que decide ou endossa, mesmo em esferas do direito aparentemente não análogas (DWORKIN, 2003, p. 204).

Tem-se, então, nesta perspectiva, mais do que a concepção da força cogente e normativa dos princípios, mas, sim, a desnecessidade de diferenciação entre eles e as regras já que o direito seria formado unicamente por princípios com vistas a uma integridade do todo que concorre para regular as partes no caso concreto (OMMATI, 2015, p. 167-168).

Todavia, é a partir desta compreensão que se tem a derrocada do Estado Legislativo de Direito e passa-se a abrir, no cenário mundial, a perspectiva de um Judiciário mais ativo e protagonista - com liberdade interpretativa consubstanciada na ótica da hermenêutica filosófica.

O juiz passa a ser o meio instrumental mais direto - seja pela atividade cognitiva que permitirá a fundamentação de sua decisão, seja pela hermenêutica jurídica pautada na interpretação, compreensão e aplicação - da concretização das normas constitucionais culminando, em algumas situações, no que pode ser denominado ativismo judicial.

Em diferentes partes do mundo, em épocas diversas, cortes constitucionais ou supremas cortes destacaram-se em determinadas quadras históricas como protagonistas de decisões envolvendo questões de largo alcance político, implementação de políticas públicas ou escolhas morais em temas controvertidos na sociedade (BARROSO, 2010, p. 17).

O ativismo judicial trata-se, então, de uma postura expansiva e proativa do intérprete da Constituição:

\begin{abstract}
A ideia de ativismo judicial está associada a uma participação mais ampla e intensa do Judiciário na concretização dos valores e fins constitucionais, com maior interferência no espaço de atuação dos outros dois Poderes. A postura ativista se manifesta por meio de diferentes condutas, que incluem: (i) a aplicação direta da Constituição a situações não expressamente contempladas em seu texto e independentemente de manifestação do legislador ordinário; (ii) a declaração de inconstitucionalidade de atos normativos emanados do legislador, com base em critérios menos rígidos que os de patente e ostensiva violação da Constituição; (iii) a imposição de condutas ou de abstenções ao Poder Público, notadamente em matéria de políticas públicas (BARROSO, 2010, p. 6).
\end{abstract}

Há que se mencionar, todavia, que existe uma confusão entre o chamado ativismo judicial e o decisionismo crasso. As tipicidades das funções dos três poderes obrigam a 
atuação positiva de todos eles, incluindo o judiciário. Tem-se, ainda, conforme disposto na própria Constituição que, na falta de atuação dos poderes Legislativo e Executivo, ao Judiciário caberá o papel de aplicação dos direitos e a concretização dos direitos previstos na Constituição. O Judiciário, então, na ausência de atuação positiva dos demais, é chamado ao ativismo pela própria Constituição.

Nestes termos, compreende-se aqui, que o ativismo judicial não é, por si, algo que coloca o Estado Democrático de Direito em situação de vulnerabilidade e desequilibra as medidas de "checks and balances" previstas para limitar os excessos cometidos pelos poderes estatais. Para o não desvirtuamento da posição ativista - isto é, para que este ativismo não passe a se tornar mero decisionismo crasso - as obrigações desses intérpretes devem perpassar pela fundamentação exaustiva das decisões e a fiel observância ao contraditório e ampla defesa.

Nos termos de Arcelo, (2016, pg. 117), a exaustiva fundamentação, com vistas à construção sólida do nexo causal entre situação factual e norma decisória é a que garantirá o fortalecimento da Constituição, a não violabilidade das funções típicas dos poderes e a construção de uma concretização normativa no contexto social capaz de dar ao elemento mais relevante da formação do Estado - o povo - a satisfação dos seus direitos.

\section{DAS IMPLICAÇÕES E RESULTADOS DO PÓS POSITIVISMO NO BRASIL}

Compreendendo que o PósPositivismo - seja na perspectiva de se enxergar os princípios como normas e o sistema do ordenamento jurídico como um todo integrado, seja, na perspectiva da ponderação - não tem o viés de conceder ao Judiciário um ativismo que comprometa o ordem democrática mas, sim, ao revés, possibilitar a realizabilidade social a partir do fiel seguimento ao devido processo legal, ampla defesa e contraditório é cediço que o PósPositivismo, em confronto com o ideário positivista kelseniano, trata-se de um paradigma incontestavelmente mais humanizado e possibilitador do alcance dos direitos.

A Constituição de 1988 - constituição cidadã, nos termos de Rui Barbosa - elencou os princípios como estruturas edificantes do sistema normativo do país. Tanto é verdade que a base ideológica da Constituição é o princípio da dignidade humana - demonstrando, neste viés, a completa orientação neoconstitucionalista da vigente Carta Maior.

Rev. de Teorias e Filosofias do Estado | e-ISSN: 2525-9652 | Porto Alegre | v. 4 | n. 2 | p. 01 - 17 | Jul/Dez. 2018 
Até sua concepção, a Lei no Brasil era eminentemente mais relevante que os textos constitucionais. A pouca força normativa das Constituições anteriores à CRFB/88 demonstrase, exemplificativamente e de forma não taxativa, na Constituição de 1824 - que tinha como realidade social a escravidão e, em seu corpo falava sobre igualdade; a Constituição de 1891 que versava sobre o sufrágio universal - mas, tinha na perspectiva da realizabilidade, uma instabilidade dos processos e votos chamados de "cabresto"; a de 1937, em que pese a disciplina do Poder Legislativo, não obstou o fechamento do Congresso - fora a ditadura militar de 64.

O processo, todavia, de realizabilidade social, encontra-se longe do projeto de nação idealizado pela Constituição de 88 . Na prática dos tribunais, os princípios continuam sendo considerados valores abstratos ou utilizados, na hermenêutica interpretativa, na medida dos interesses políticos vigentes.

Um retorno à data de promulgação da Constituição, permite enxergar que, nenhuma estrutura de poder abstraída de projetos de governo, em tese, diametralmente opostos envolvendo partidos de suposta esquerda e de direita - envidaram esforços para a consolidação de um Estado Democrático de Direito. Seja pela perspectiva de um Estado Social arraigado aos primeiros, seja por uma compreensão liberal ou neoliberal insistente no segundo, reproduzimos paradigmas que, comprovadamente, não conseguiram obter êxito no projeto moderno de civilização.

A utilização exacerbada de Medidas Provisórias para governar, seja no governo Collor, seja no governo Lula e, atualmente, na gestão do Governo Temer - indicam o sucateamento basilar do processo de "check and balances" da teoria tripartipe dos Poderes.

Relevante destacar, ainda, na contemporaneidade, as recentes decisões do Supremo Tribunal Federal onde princípios constitucionais foram relativizados - configurando não o ativismo judicial, mas um mero decisionismo crasso. A execução da pena após condenação em segunda instância é, num processo hermenêutico-interpretativo, não tão paradoxal. Todavia, por meio do indeferimento de liminares das Ações Diretas de Constitucionalidade (ADCs) 43 e 44, por maioria, o plenário do STF entendeu que o Art. 238 do Código de Processo Penal não impede o início da execução das penas após a condenação em segunda instância já em 2016 - o que culminou na fatídica votação do habeas corpus do presidente Luís Inácio Lula da Silva.

Rev. de Teorias e Filosofias do Estado | e-ISSN: 2525-9652 | Porto Alegre | v. 4 | n. 2 | p. 01 - 17 | Jul/Dez. 2018 
A operação Lava-jato, por sua vez, sobrepostos os possíveis benefícios populares que possam, por ventura, serem alegados, demonstram, em consideráveis ações da polícia e do judiciário, o grande retrocesso na compreensão principiológica garantista da Constituição.

O vazamento de áudios de uma investigação, amplamente ocorrido durante as investigações, de uma forma estarrecedora, colocam em cheque toda a credibilidade das instituições de apuração e do judiciário. O sigilo de provas na fase inquisitorial é o único meio possível de resguardar o contraditório - já que, sem ele, a culpabilidade é presumida, em arrepio ao princípio constitucional disposto no Art. $5^{\circ}$ da Constituição da República Federativa do Brasil. É inadmissível que aceitemos que um juiz possa, nesta via, solicitar a produção de provas por ofício dentro de um processo acusatório perquirido pela Constituição.

A própria legislação da delação premiada - amplamente utilizada na operação lavajato - demonstra-se, hoje, como um mecanismo reverso de se recolocar a antiga rainha das provas (confissão) em evidência, contraindo séculos de compreensão e humanização do Direito Penal.

Não estamos, todavia, adstritos aos desmandos do Judiciário. O Legislativo, com o processo de impeachment e por intermédio de propostas de lei que relativizam direitos já consolidados (como os realizados pela bancada BBB - boi, bíblia e bala) demonstram, todos os dias, a fragilidade dos direitos conquistados e a abstração e relativização principiológica disposta na Constituição. Tal processo não se sustentaria numa ótica principiológica e, nem tampouco, de regramento infraconstitucional. A reprovação de contas públicas que, conforme Galuppo (2016, p.87), nem sequer é ato do Presidente da República e, consequentemente, trata-se de disposição ausente nos atos taxativos que ensejam crimes de responsabilidade de um(a) presidente(a) dispostos no Art. $4^{\circ}$ da Lei Federal $n^{\circ}$ 1079/50, ressoam a defensável ilegalidade da ação.

O retrocesso no uso das compreensões neoconstitucionalistas por interesse político também pode ser visto no Executivo - a partir do governo Temer, por meio de uma sequência de direitos sociais mitigados e, principalmente, por meio da Proposta de Emenda à Constituição 241 - que objetiva, em última instância, paralisar investimentos em áreas sociais com a ideia de que tal ação possa gerar ganhos econômicos significativos para o país.

Neste breve sobrevoo sobre a situação atual do Brasil, nota-se, de forma insistente que não engatinhamos na estruturação de um Estado Democrático de Direito, e sim que, na verdade, que este Estado Democrático ainda não existe e nem nunca existiu no Brasil. Trata- 
se, ainda, mesmo nos quase 30 anos de Constituição, de um projeto que, pelo viés de dificuldades políticas atuais, tende a se afastar cada vez mais de sua base ideológica.

\section{CONSIDERAÇÕES FINAIS}

A perseguição de um projeto político-social através do uso das instituições públicas e o decisionismo crasso do judiciário brasileiro permitem indicar que é possível que o judiciário brasileiro não possua maturidade suficiente para as premissas de teorias pospositivas. Se elas nem foram devidamente implantadas ainda e já são utilizadas para fins escusos ao objetivo da realizabilidade social, talvez a melhor opção estaria em darmos um passo atrás nos modelos técnico-jurídicos.

Há que mencionar, contudo, que a adoção de teorias positivas - exatamente pelo giro decisionista reconhecido até mesmo por Kelsen e o poder fluido da linguagem, não salvaguardariam o país de desmandos constitucionais havendo interesse na subversão dos preceitos democráticos do país.

Não podendo, pois, sustentar os ideais democráticos no positivismo tradicional, nem tampouco, conforme se demonstrou, integralmente no PósPositivismo já que há uma adulteração da dimensão semântica do direito, um recuo técnico-jurídico poderia ser a base para a reestruturação das garantias e direitos fundamentais.

Nesta via, a partir da noção contingencial da moral, talvez o único espaço para a garantia do princípio da efetividade dos direitos seja a adoção de um positivismo inclusivo onde as matérias contingentes e morais dependam daquilo que o direito positivo de fato diz.

O que se sustenta é que, adotando teorias mais limitadoras da abrangência interpretativa como o positivismo inclusivo, talvez tenhamos uma possibilidade de diminuirmos os malabarismos judiciais.

\section{REFERÊNCIAS}

ARCELO, A. COSTA, Bárbara Amelize. Normas declaratórias de princípios programáticos no Estado Democrático de Direito e a Constitucionalização Simbólica. In: XXV ENCONTRO NACIONAL DO CONPEDI - BRASÍLIA/DF, 2016, Brasília. TEORIAS DO DIREITO E REALISMO JURÍDICO. Florianópolis: Conselho Nacional de Pesquisa e Pós-Graduação em Direito (CONPEDI), 2016. v.XXV. p.310 - 328. Referências adicionais :

Rev. de Teorias e Filosofias do Estado | e-ISSN: 2525-9652 | Porto Alegre | v. 4 | n. 2 | p. 01 - 17 | Jul/Dez. 2018 
Brasil/Português. Meio de divulgação: Meio digital. Home page: [http://www.conpedi.org.br/publicacoes/y0ii48h0/p9j98k25/1Za2RWC9478rwE60.pdf]

ALEXY, Robert. Teoría de los Derechos Fundamentales. $1^{a}$ reimpressão. Madrid: Centro de Estudios Constitucionales, 1997.

BOBBIO, Norberto. Teoria da norma jurídica. Tradução: Fernando Pavam Baptista e Ariani Bueno Sudatti. Apresentação Alaôr Caffé Alves. Bauru, SP. Editora Edipro, 2a ed. revista, 2003.

BONAVIDES, Paulo. Curso de Direito Constitucional. São Paulo: Malheiros Editores, 1994.

BARROSO, Luís Roberto. Judicialização, Ativismo Judicial e Legitimidade Democrática. Revista da Escola de Magistratura Regional Federal. 1. vol. 2010.

DWORKIN, Ronald. O Domínio da Vida: Aborto, Eutanásia e Liberdades Individuais. São Paulo: Martins Fontes, 2003.

GADAMER, Hans-Georg. Verdade e Método: Traços Fundamentais de uma Hermenêutica Filosófica. 5. ed. Petrópolis: Vozes, 2003.

GALUPPO, Marcelo Campos. Impeachment: O que é, como se processo, por que se faz. 1. Ed. Belo Horizonte: Editora D’Plácido, 2016.

HABERMAS, Jürgen. Direito e Democracia. Tradução de Flávio Beno Siebeneichler. 4. ed. 1. vol. Rio de Janeiro: Edições Tempo Brasileiro, 1997. 354 pgs.

HEIDEGGER, Martin. Ser e Tempo. Tradução: Benedito Nunes. 3. ed. Rio de Janeiro: Jorge Zahar Editor Ltda, 2010

KELSEN, Hans. Teoria Pura do Direito. 6. ed. $3^{\text {a }}$ tiragem. São Paulo: Martins Fontes, 1999.

KUHN, Thomas S. A Estrutura das Revoluções Científicas. 5. ed. São Paulo: Perspectiva, 1997.

MAGAlHÃES, José Luiz Quadros de. Direito Constitucional, Tomo I. 2. ed. Belo Horizonte: Livraria Mandamentos Editora, 2002.

NUSSBAUM, Marta C.; SHOR, Ira; Justicia Poetica: La imaginación literaria y la vida pública; Traducción de Calos Gardini. Editora Andres Bello. México, DF, 1997. 2. ed. 193 pgs.

OMMATI. José Emílio Medauar. Teoria da Constituição. Rio de Janeiro: Editora Lumen Juris, 2015. 
SÓFOCLES. Antígona. Tradução: J.B. de Mello e Souza. Obra original escrita entre 496 AC e 406 AC. Editora: ebookseletronics.org, Clássicos Jackson, Vol XXII, 2005, 89 pgs. Disponível em: http://www.ebooksbrasil.org/adobeebook/antigone.pdf

WITTGENSTEIN, Ludwig. Investigações Filosóficas. 2. ed. Petrópolis: Vozes, 1996. 